DOI: $10.7242 / 1998-2097 / 2018.3 .7$

УДК 324

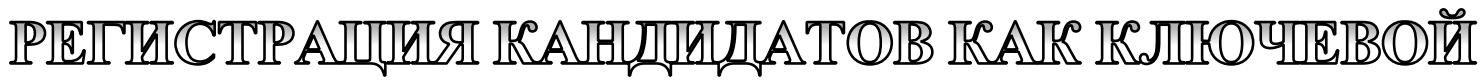

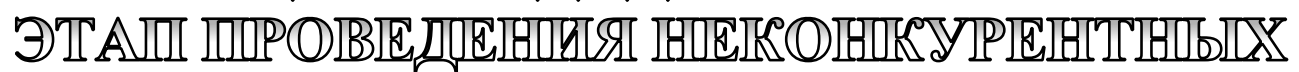

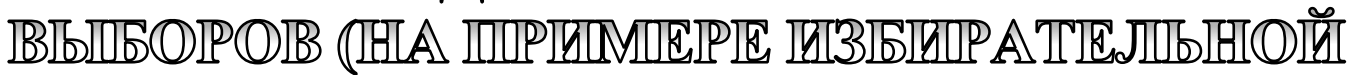

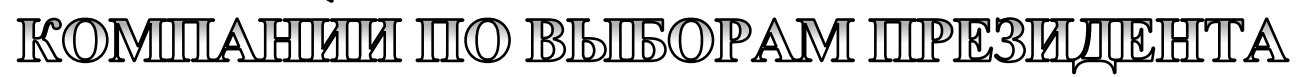

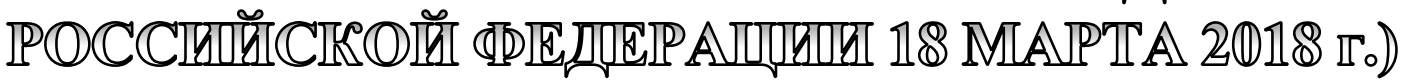

В.С. Ковин, Пермский федеральный исследовательский центр УрО РАН

Рассматриваются начальные этапы избирательной кампании по выборам Президента Российской Федерации 2018 года - выдвижение и регистрация кандидатов. Анализируется состав участников, причины их регистрации или нерегистрации. Делается вывод о целенаправленной политике по проведению неконкурентных кампаний по выборам глав исполнительной власти (на примере президентской кампании) как основной тенденции управления электоральными процессами в современной России. Рассматриваются основные механизмы по реализации этой задачи. Заключается, что основной акцент в управлении выборами перенесен на вырабатывание таких формальных правил, которые в состоянии преодолеть только системные и ресурсные политики.

Ключевые слова: президентские выборы, конкуренция, регистрация кандидатов, избирательная кампания.

Выборы Президента России, состоявшиеся 18 марта 2018 г., стали квинтэссенцией электоральной политики, реализуемой в современной России. Вскоре после восстановления прямых выборов глав регионов и некоторых экспериментов в 2012-2013 гг. с конкуренцией на них (например, выборы губернатора Иркутской области 2015 г.) Кремлем был взят курс на проведение неконкурентных кампаний по избранию глав исполнительной власти, где будущий победитель определялся задолго до дня голосования, а наиболее

серьезные конкуренты отсеивались либо на предварительных стадиях ${ }^{1}$, либо на этапе регистрации ${ }^{2}[9]$. В связи с этим мало что предвещало избрание действующей властью иной стратегии при проведении президентских выборов 2018 г. Однако, учитывая опыт политических скандалов во время ряда прошедших региональных кампаний, фильтрация участников предстоящих президентских выборов должна была носить строго формальный и легальный характер, оставляя за избирательной системой возможность приня-

\footnotetext{
${ }^{1}$ Например, отказы в выдвижении перспективных кандидатов от оппозиционных партий на выборах глав в ряде регионов в 2017 г. (Республика Карелия, Республика Марий Эл, Рязанская область, Свердловская область, г. Севастополь и др).

${ }^{2}$ Например, отказы в регистрации сильных кандидатов по причине невозможности прохождения «муниципального фильтра» в Пермском крае, Бурятии и других регионах.
} 
тия лишь чисто технических решений. Для этого была подготовлена соответствующая юридическая база.

Президентская кампания 2018 г. прошла на основе законодательства, существенно отличающегося от того, по которому проводились предыдущие президентские выборы в марте 2012 г. Давно отмечено, что российское избирательное законодательство отличается крайней нестабильностью, а его изменения зачастую носят конъюнктурный политический характер. За период 2012-2017 гг. изменения в Федеральный закон «О выборах Президента Российской Федерации» вносились 15 раз, в общей сложности были изменены 59 из 87 статей и все четыре приложения данного закона [8]. Кроме того, были изменены положения Федерального закона № 67 «Об основных гарантиях избирательных прав и права на участие в референдуме граждан Российской Федерации», которые также имеют отношение к выборам Президента России: образование избирательных участков, формирование участковых избирательных комиссий, сроки обжалования итогов голосования и результатов выборов [15].

При этом изменения законодательства имели разнонаправленный характер. К новеллам, которые способствовали некоторой демократизации избирательного процесса и потенциально могли привести к росту конкурентности выборов, можно отнести: резкое сокращение числа требуемых для регистрации кандидата подписей избирателей с 2 млн до 100 тыс. для кандидатов, выдвинутых от непарламентских партий, и до 300 тыс. - для кандидатов-самовыдвиженцев; обеспечение возможностей для голосования граждан, живущих не по месту регистрации (что затрагивает, прежде всего, жителей больших городов), некоторые послабления для организации наблюдения в день голосования. Однако большая часть изменений 2012-2016 гг. имела противоположную направленность: новые ограничения пассивного избирательного права, дополнительные ограничения при регистрации кандидата, сокращение сроков обжалования итогов голосования и результатов выборов.

Можно утверждать, что указанные выше изменения оказали значимое влияние на ход президентской избирательной кампании 2018 г., поскольку в итоге привели к существенному снижению уровня конкурентности выборов. В частности, это касается различий в требованиях к кандидатам от парламентских и непарламентских партий и к кандидатамсамовыдвиженцам.

Как видно из рис. 1, в рамках кампании 2018 г. сохранилось правовое неравенство возможностей кандидатов от партий, представленных в Государственной Думе, по отношению к кандидатам от

\begin{tabular}{|c|c|c|}
\hline & $\begin{array}{c}\text { Категории кандидатов на выборах } \\
\text { Президента России }\end{array}$ & \\
\hline $\begin{array}{l}\text { Кандидаты от парламентских } \\
\text { партий } \\
\text { - наличие пассивного } \\
\text { избирательного права } \\
\text { - выдвижение на съезде партии } \\
\text { (мин. } 43 \text { делегата) } \\
\text { - предоставление необходимых } \\
\text { документов } \\
\text { - открытие избирательного } \\
\text { счета }\end{array}$ & $\begin{array}{l}\text { Кандидаты от } \\
\text { непарламентских партий } \\
\text { - наличие пассивного } \\
\text { избирательного права } \\
\text { - выдвижение на съезде партии } \\
\text { (мин. } 43 \text { делегата) } \\
\text { - предоставление необходимых } \\
\text { документов } \\
\text { - открытие избирательного } \\
\text { счета } \\
\text { - сбор } 100 \text { тыс. подписей } \\
\text { избирателей }\end{array}$ & $\begin{array}{l}\text { Кандидаты - самовыдвиженцы } \\
\text { - наличие пассивного } \\
\text { избирательного права } \\
\text { - выдвижение на собрании } \\
\text { инициативной группы (мин. } \\
500 \text { участников) } \\
\text { - предоставление необходимых } \\
\text { документов } \\
\text { - открытие избирательного } \\
\text { счета } \\
\text { - сбор } 300 \text { тыс. подписей } \\
\text { избирателей }\end{array}$ \\
\hline
\end{tabular}

Рис. 1. Условия регистрации кандидатов 
иных партий и кандидатам-самовыдвиженцам. Оно выражается в том, что кандидаты, выдвинувшиеся от парламентской партии, освобождаются от необходимости сбора подписей и могут сразу приступить к ведению полномасштабной агитационной кампании, что и сделали кандидаты, выдвинутые от КПРФ (Павел Грудинин) и ЛДПР (Владимир Жириновский).

В наиболее затруднительном положении оказались представители непарламентских партий, которые, в отличие от четырех думских партий, не получают государственного финансирования, но, помимо выполнения аналогичных требований по организации выдвижения своих кандидатов, должны собрать необходимое количество подписей избирателей, что само по себе является весьма ресурсно затратным в масштабах страны и до момента проверки собранных подписей не позволяет развернуть агитационную кампанию. Кроме того, ход кампании показал, что барьер в 300 тыс. подписей избирателей преодолим только для кандидата, обладающего значительными административными, финансовыми и организационными ресурсами (как действующий президент В. Путин).

Все же важнейшее влияние на ход и конкурентность текущих выборов оказали дополнительные ограничения пассивного избирательного права. Согласно закону от 21.02.2014 г. № 19-Ф3 [13] пассивного избирательного права были лишены лица, осужденные к лишению свободы за совершение тяжких преступлений до истечения 10 лет со дня снятия или погашения судимости, а лица, осужденные к лишению свободы за совершение особо тяжких преступлений - до истечения 15 лет со дня снятия или погашения судимости. Именно на этом основании до выборов не был допущен политик Алексей Навальный, который еще в конце 2016 г. объявил о своем намерении участвовать в президентской кампании. На протяжении всего 2017 г. он вел публичную политическую кампанию, создал сеть предвыборных штабов в регионах России, заручился поддержкой значительного числа сторонников, инициировал проведение самых крупных за последние несколько лет политических акций [3].

Закон от 07.05.2013 г. № 102-Ф3 [14] предусмотрел, что кандидат обязан до момента предоставления необходимых документов в ЦИК РФ, т.е. еще до своей регистрации в качестве кандидата, закрыть счета (вклады), прекратить хранение наличных денежных средств и ценностей в иностранных банках, расположенных за пределами территории Российской Федерации, и (или) осуществить отчуждение иностранных финансовых инструментов, если таковые имеются. Невыполнение этих требований также является основанием для отказа в регистрации кандидата. Данные требования стали ограничением для участия в выборах для потенциальных кандидатов из числа бизнесменов, так как они не могут себе позволить столь заблаговременный отказ от использования иностранных финансовых инструментов, не будучи уверенными в допуске к участию в кампании.

Первоначально старт избирательной кампании создал некоторую надежду на проведение конкурентных выборов. ЦИК России получила уведомления о проведении мероприятий, связанных с выдвижением кандидатов на должность Президента РФ, от 70 субъектов выдвижения: 24 политических партий и 46 граждан, заявивших о своем самовыдвижении [11]. Так или иначе, практически все наиболее значимые политические объединения выдвинули своих кандидатов, формально за исключением думских партий «Единая Россия» и «Справедливая Россия», а также некоторых малых партий (например «Патриоты России»), представленных в ряде региональных парламентов, которые поддержали самовыдвижение В. Путина. Документы по итогам проведения процедуры выдвижения в ЦИК РФ представили только 36 
Итоги выдвижения кандидатов на выборах президента России в 2018 г.

\begin{tabular}{|c|c|c|}
\hline Кандидат & Партия или самовыдвижение & Решение ЦИК РФ \\
\hline Жириновский В.В. & ЛДПР & регистр. \\
\hline Семерикова Е.Г. & «Женский диалог» & отказ \\
\hline Титов Б.Ю. & Партия Роста & регистр. \\
\hline Лисицына Н.С. & «РОТ ФРОнТ» & отказ \\
\hline Худяков Р.И. & «ЧЕСТHO» & регистр. \\
\hline Агурбаш Э.К. & «Альянс Зеленых» & регистр. \\
\hline Явлинский Г.А. & «Яблоко» & регистр. \\
\hline Бабурин С.Н. & «Российский Общенародный союз» & регистр. \\
\hline Собчак К.А. & «Гражданская инициатива» & регистр. \\
\hline Полищук С.П. & Партия Социальных Реформ & регистр. \\
\hline Баков А.А. & Монархическая партия & регистр. \\
\hline Рамазанов С.О. & СДПР & регистр. \\
\hline Гордон Е.В. & «Партия “Добрых дел”» & регистр. \\
\hline Грудинин П.Н. & КПРФ & регистр. \\
\hline Козлов М.В. & Партия Социальной Защиты & регистр. \\
\hline Сидоров Ю.П. & Партия малого бизнеса & отказ \\
\hline Сурайкин М.А. & «Коммунистическая партия “Коммунисты России”» & регистр. \\
\hline Полонский С.Ю. & самовыдвижение & отказ \\
\hline Воловик Т.А. & самовыдвижение & отказ \\
\hline Навальный А.А. & самовыдвижение & отказ \\
\hline Лурье О.А. & самовыдвижение & отказ \\
\hline Чухлебов А.Ю. & самовыдвижение & регистр. \\
\hline Михайлов В.В. & самовыдвижение & регистр. \\
\hline Путин В.B. & самовыдвижение & регистр. \\
\hline Яцун А.Н. & самовыдвижение & отказ \\
\hline Присягин Т.А. & самовыдвижение & отказ \\
\hline Лисицына Н.С. & «РОТ ФронТ» (повторно) & регистр. \\
\hline Гамзатова А.З. & самовыдвижение & отказ \\
\hline Ли Лаки & самовыдвижение & отказ \\
\hline Волынец И.В. & «Народ против коррупции» & отказ \\
\hline Черепнин В.В. & самовыдвижение & отказ \\
\hline Пугачев В.В. & самовыдвижение & отказ \\
\hline Гагитэ И.М. & Российская социалистическая партия & снялась \\
\hline Кузнецов В.Е. & самовыдвижение & отказ \\
\hline Столпак С.П. & самовыдвижение & отказ \\
\hline Волынец И.В. & Народная партия России & регистр. \\
\hline Булаев О.А. & КПСС & Снялся \\
\hline Копенкина М.П. & Родная партия & отказ \\
\hline
\end{tabular}

- зарегистрированные кандидаты

- кандидаты, получившие право на сбор подписей избирателей

- кандидаты, не допущенные до сбора подписей избирателей

- кандидаты, снявшиеся с выборов

кандидатов: 21 выдвинутых партиями (два кандидата, Н.С. Лисицына и И.В. Волынец выдвинулись дважды) и 15 самовыдвиженцев [11].

Стоит отметить, что профессиональный состав выдвинувшихся кандидатов оказался достаточно разнообразным. Среди них преобладали профессиональные политики (13 человек, включая В. Пути- на, В. Жириновского, С. Бабурина, А. Навального, Б. Титова) и предприниматели (11 человек, в том числе П. Грудинин, С. Полонский). Выдвинулись также общественники (Т.А. Воловик, И.В. Волынец, Т.А. Присягин, В.В. Пугачев, С.П. Столпак) и журналисты (А.З. Гамзатова, Е.В. Гордон, О.А. Лурье, К.А. Собчак), а также представители «рабочих» 
(крановщица Н.С. Лисицына) и «современных» профессий (программист В.В. Черепнин) [1]. Обращает на себя внимание отсутствие представителей бюджетной сферы и пенсионеров. В целом можно отметить, что политическая сфера в России постепенно профессионализируется.

Между тем определенные сомнения вызывала сама серьезность намерений некоторых партий и кандидатов принять реальное участие в президентских выборах, поскольку они не смогли осуществить ряд необходимых процедур. На этапе выдвижения ЦИК России приняла положительные решения (о регистрации группы избирателей или уполномоченных представителей партии) в отношении 19 кандидатов (16 выдвиженцев партий и 3 самовыдвиженцев). Однако два кандидата быстро выбыли: лидер и выдвиженец «Социал-демократической партии» России С.О. Рамазанов сразу после принятия решения ЦИК объявил, что партия приняла решение об отказе от участия в выбоpax и поддержала Владимира Путина; регистрация группы избирателей в поддержку выдвижения А.Ю. Чухлебова была отменена Верховным Судом РФ. Представителям четырех партий («Женский
Диалог», «Партия Малого Бизнеса России», «Народ против коррупции», «Родная партия») было отказано в регистрации уполномоченных представителей в связи с нарушениями при проведении съездов и отсутствия необходимых документов. 15 января в ходе заседания ЦИК России сняла свою кандидатуру И.М. Гагитэ («Российская Социалистическая партия») в связи с подозрениями в фальсификации сданных ею на регистрацию документов. Таким образом, после первого этапа (этапа выдвижения) лишь 17 из 36 кандидатов продолжили участие в избирательной кампании.

Рис. 2 показывает еще одну тенденцию - неуклонное сокращение числа кандидатов-самовыдвиженцев, участвовавших в президентских избирательных кампаниях. В качестве одного из двух самовыдвиженцев на выборы 2018 г. выдвинулся Владимир Путин - это, безусловно, чисто тактический ход. Возможность его выдвижения от партии «Единая Россия» долго обсуждалась и была вполне реальной. Число кандидатов, выдвинувшихся от партий, оставалось до текущей избирательной кампании примерно на одном уровне (3-5 кандидатов), что отражает недостаточную разви-

$\square$ самовыдвиженцы $\square$ кандидаты от партий $\square$ смешаное выдвижение

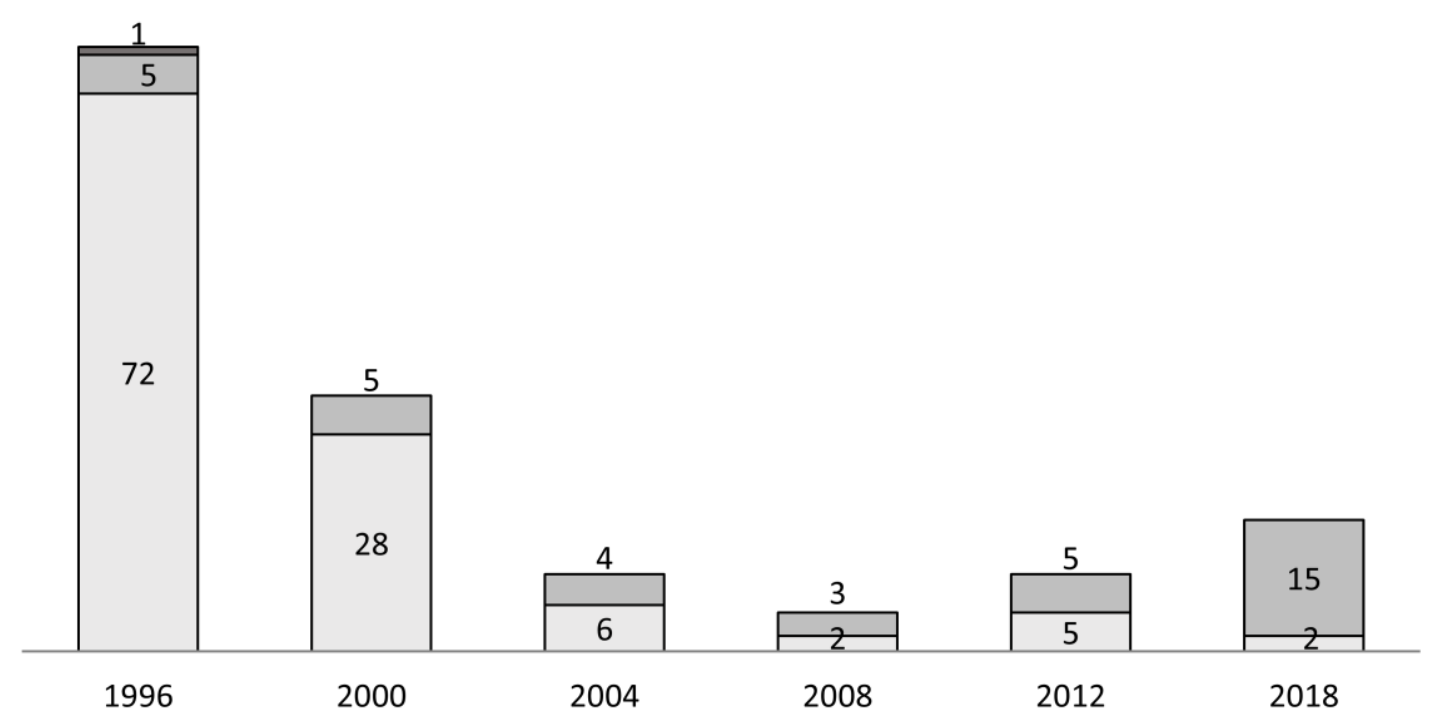

Рис. 2. Количество кандидатов и субъекты их выдвижения 
тость партийной системы в России. В 2000-е гг. в основном своих кандидатов выдвигали политические партии, представленные в Государственной Думе (так называемые «парламентские партии»). Рост числа выдвиженцев от политических партий объясняется не столько ростом политического влияния партий, сколько либерализацией партийного законодательства в отношении создания партий, осуществленной в 2011-2012 гг. Но главное - партиям необходимо собрать в три раза меньше подписей избирателей в поддержку выдвижения кандидата, чем кандидату-самовыдвиженцу (100 тыс. против 300 тыс.). К тому же две парламентские партии, «Единая Россия» и «Справедливая Россия», формально не выдвинули своего кандидата, а поддержали действующего президента Владимира Путина.

Президентская избирательная кампания официально была объявлена лишь 18 декабря 2017 г. после публикации решения Совета Федерации России, хотя закон позволял это сделать намного раньше. Этап выдвижения кандидатов продлился до 12 января 2018 г. Представляется, что начало кампании было сознательно оттянуто по сравнению с наиболее ранним возможным сроком (7 декабря) на 11 дней. В результате кандидатами или партиями были потеряны почти две недели, что чрезвычайно важно для самовыдвиженцев и непарламентских партий, которые смогли приступить к полномасштабному сбору подписей лишь после новогодних каникул [6]. При этом крайний срок представления подписей в ЦИК России жестко зафиксирован в законе - это 31 января. Поздняя публикация решения о назначении выборов создала дополнительные сложности для кандидатов, некоторые из них попали в положение цейтнота, из которого так и не смогли успешно выбраться.

В результате, после завершения первого этапа избирательной кампании - этапа выдвижения - в ней осталось 2 кандидатасамовыдвиженца (В.В. Путин и В.В. Михайлов, депутат Костромской областной Думы) и 15 кандидатов на должность президента России, выдвинутых политическими партиями: 1. Э.К. Агурбаш («Альянс Зеленых»), 2. С.Н. Бабурин («Российский Общенародный Союз»), 3. А.А. Баков («Монархическая партия»), 4. Е.В. Гордон («Партия “Добрых дел”»), 5. П.Н. Грудинин (КПРФ), 6. В.В. Жириновский (ЛДПР), 7. М.В. Козлов («Партия Социальной Защиты»), 8. Н.С. Лисицына («РОТ Фронт»), 9. С.П. Полищук («Партия Социальных Реформ Прибыль от природных ресурсов - Народу»), 10. К.А. Собчак («Гражданская инициатива»), 11. М.А. Сурайкин («Коммунисты России»), 12. Б.Ю. Титов («Партия Роста»), 13. Р.И. Худяков («ЧЕСТНО»/ Человек. Справедливость. Ответственность»/), 14. Г.А. Явлинский («Яблоко»), 15. И.В. Волынец («Народная партия России»).

Из них 12 кандидатов на законных основаниях смогли приступить к сбору подписей избирателей. Кандидаты П.Н. Грудинин от КПРФ и В.В. Жириновский от ЛДПР, как кандидаты от парламентских партий, были освобождены от необходимости сбора подписей.

В целом, уровень отсева кандидатов уже на этапе выдвижения оказался значительно выше, чем во время президентских избирательных кампаний в 2000, 2004 и 2012 гг. и составил более 50\%.

Первоначально ЦИК зарегистрировала три группы избирателей, созданные в поддержку самовыдвижения кандидатов В.В. Путина, В.В. Михайлова и А.Ю. Чухлебова. Однако 5 января 2018 г. выдвижение кандидата Чухлебова, по инициативе самой ЦИК России, было отменено решением Верховного суда. ЦИК посчитала, что он обладает видом на жительство в Финляндии, хотя в ноябре 2017 г. этот вид на жительство властями Финляндии аннулирован, но данный факт не был подтвержден на территории России. Более того, оказалось, что российское законодательство не предусматривает подачу уведомления о прекращении вида на жительство на территории иностранного государства и формы его не существует. В результате, несовершенство российского законодательства привело к поражению в избирательных правах одного из российских граждан [5]. 
Кандидаты, не прошедшие этап выдвижения

\begin{tabular}{|c|c|c|}
\hline Кандидат & $\begin{array}{l}\text { Партия или } \\
\text { самовыдви- } \\
\text { жение }\end{array}$ & Основание для отказа \\
\hline $\begin{array}{l}\text { Семерикова } \\
\text { Е.Г. }\end{array}$ & $\begin{array}{l}\text { «Женский } \\
\text { диалог» }\end{array}$ & $\begin{array}{l}\text { Меньшая, чем требуется по закону, численность делегатов съезда } \\
\text { партии (менее 43) }\end{array}$ \\
\hline $\begin{array}{l}\text { Лисицына } \\
\text { Н.С. }\end{array}$ & «РОТ Фронт» & $\begin{array}{l}\text { Позднее уведомление ЦИК РФ о проведении съезда партии (менее } 3 \\
\text { дней), хотя представители ЦИК на съезде присутствовали; } \\
\text { непредставление одного из необходимых документов (документ о } \\
\text { крупных расходах) }\end{array}$ \\
\hline $\begin{array}{l}\text { Сидоров } \\
\text { Ю.П. }\end{array}$ & $\begin{array}{l}\text { «Партия малого } \\
\text { бизнеса» }\end{array}$ & $\begin{array}{l}\text { Меньшая, чем требуется по закону, численность делегатов съезда } \\
\text { партии (менее 43) }\end{array}$ \\
\hline $\begin{array}{l}\text { Полонский } \\
\text { С.Ю. }\end{array}$ & самовыдвижение & $\begin{array}{l}\text { Меньшая, чем требуется по закону, численность группы избирателей } \\
\text { (менее } 500 \text { чел.) }\end{array}$ \\
\hline Воловик Т.А. & самовыдвижение & $\begin{array}{l}\text { Непредставление одного из необходимых документов (нотариально } \\
\text { удостоверенную доверенность на уполномоченного представителя по } \\
\text { финансовым вопросам); отсутствие регистрации на момент открытия } \\
\text { собрания необходимых } 500 \text { участников. }\end{array}$ \\
\hline $\begin{array}{l}\text { Навальный } \\
\text { А.А. }\end{array}$ & самовыдвижение & $\begin{array}{l}\text { Отсутствие пассивного избирательного права из-за наличия судимости } \\
\text { за преступления }\end{array}$ \\
\hline Лурье О.А. & самовыдвижение & $\begin{array}{l}\text { Отсутствие пассивного избирательного права из-за наличия судимости } \\
\text { за преступления; меньшая, чем требуется по закону, численность } \\
\text { группы избирателей }\end{array}$ \\
\hline $\begin{array}{l}\text { Чухлебов А. } \\
\text { Ю. }\end{array}$ & самовыдвижение & $\begin{array}{l}\text { Отмена регистрации по решению суда из-за наличия вида на } \\
\text { жительство иностранного государства (Финляндия) }\end{array}$ \\
\hline Яцун А.Н. & самовыдвижение & $\begin{array}{l}\text { Непредставление одного из необходимых документов (нотариально } \\
\text { удостоверенной доверенности на уполномоченного представителя по } \\
\text { финансовым вопросам); неправильное оформление одного из } \\
\text { документов }\end{array}$ \\
\hline $\begin{array}{l}\text { Присягин } \\
\text { T.A. }\end{array}$ & самовыдвижение & $\begin{array}{l}\text { Меньшая, чем требуется по закону, численность группы избирателей } \\
\text { (менее } 500 \text { чел.) }\end{array}$ \\
\hline $\begin{array}{l}\text { Гамзатова } \\
\text { А.3. }\end{array}$ & самовыдвижение & $\begin{array}{l}\text { Позднее уведомление ЦИК РФ о проведении съезда партии (менее } 5 \\
\text { дней); непредставление одного из необходимых документов (документ } \\
\text { о крупных расходах); неправильное оформление одного из документов }\end{array}$ \\
\hline Ли Лаки & самовыдвижение & $\begin{array}{l}\text { Меньшая, чем требуется по закону, численность группы избирателей } \\
\text { (менее } 500 \text { чел.) }\end{array}$ \\
\hline Волынец И.В. & $\begin{array}{l}\text { «Народ против } \\
\text { коррупции» }\end{array}$ & $\begin{array}{l}\text { Позднее уведомление ЦИК РФ о проведении съезда партии (менее } 5 \\
\text { дней); непредставление одного из необходимых документов (отсутствие } \\
\text { в одном из документов подписи кандидата) }\end{array}$ \\
\hline $\begin{array}{l}\text { Черепнин } \\
\text { В.В. }\end{array}$ & самовыдвижение & Меньшая, чем требуется по закону, численность группы избирателей \\
\hline Пугачев В.В. & самовыдвижение & $\begin{array}{l}\text { Позднее уведомление ЦИК РФ о проведении съезда партии (менее } 5 \\
\text { дней); неправильное офрормление одного из документов }\end{array}$ \\
\hline $\begin{array}{l}\text { Кузнецов } \\
\text { B.E. }\end{array}$ & самовыдвижение & Меньшая, чем требуется по закону, численность группы избирателей \\
\hline Столпак С.П. & самовыдвижение & $\begin{array}{l}\text { Отсутствие нотариально удостоверенного протокола регистрации } \\
\text { членов группы избирателей }\end{array}$ \\
\hline $\begin{array}{l}\text { Копенкина } \\
\text { М.П. }\end{array}$ & «Родная партия» & $\begin{array}{l}\text { Меньшая, чем требуется по закону, численность делегатов съезда } \\
\text { партии (менее } 43 \text { делегатов) }\end{array}$ \\
\hline
\end{tabular}

- выделены основания для отказа подтверждения выдвижения кандидата, которые, на взгляд экспертов, имеют сомнительный характер, поскольку нарушения кандидатов не были критичными и неустранимыми. Формально отказы на этих основаниях соответствуют букве закона, но они явно противоречат духу закона.

$\square$ - отказы в регистрации на основании спорных норм, лишающих граждан пассивного избирательного права, и в отношении которых нет консенсуса ни среди юридического сообщества, ни среди широкой общественности. Введение этих норм расценивается их критиками, в том числе, как проявление политической конъюнктуры и действие, направленное против определенных политиков. 
Наиболее напряженная политическая кампания и острая дискуссия развернулись вокруг недопуска на выборы оппозиционного политика Алексея Навального, который позиционировал себя как главный оппонент Владимира Путина. Его осуждение в июле 2013 г. по делу так называемого «Кировлеса» многими было расценено как политически ангажированное судебное решение и вызвало широкий общественный резонанс [2]. В октябpe 2013 г., уже после окончания выборов мэра Москвы, в которых политик принимал участие и занял второе место с 23,6\% голосов, суд изменил приговор и назначил Навальному условный срок, что формально закрыло ему возможность принимать участие в выборах. После отмены первого судебного решения Европейским судом по правам человека в феврале 2016 г., на основании нарушения прав Навального на справедливое судебное разбирательство, оно было в точности воспроизведено во время повторного разбирательства, завершившегося в феврале 2017 г. [2]. Политик был повторно приговорен к 5 годам лишения свободы условно. Тем не менее он продолжил вести предвыборную кампанию, которую объявил еще в декабре 2016 г. По данным центрального штаба Навального, к началу президентской кампании он имел региональные штабы в 84 городах России и более 700 тыс. сторонников, из которых более 100 тыс. заранее предъявили свои паспортные данные, чтобы предоставить подписи в его поддержку [3]. Также ему удалось собрать на кампанию более 372,7 млн рублей пожертвований [4]. В целом, можно утверждать, что Алексей Навальный заручился достаточной поддержкой избирателей и создал общенациональную политическую инфраструктуру, что необходимо для эффективного участия в выборах президента России. И все это несмотря на широкое распространение информации о наличии у него судимости, которая юридически не позволяла ему принимать участие в выборах.
24 декабря 2017 г. в 20 городах России были проведены собрания инициативных групп по выдвижению Навального кандидатом на выборах. Ocновное собрание, по итогам которого в ЦИК РФ были отправлены необходимые документы, было проведено в Москве. 25 декабря 2017 года ЦИК отказала А. Навальному в регистрации кандидатом на выборах из-за неснятой и непогашенной судимости по делу «Кировлеса». В ответ политик объявил широкомасштабную политическую кампанию бойкота президентских выборов («Забастовка избирателей») [7]. Формальное исключение из предвыборной гонки данного политика хотя и лишило его статуса кандидата, но сохранило за ним возможность оказывать политическое влияние на ход избирательной кампании.

В целом, в большинстве случаев процесс и процедуры принятия решений ЦИК России о выдвижении и регистрации кандидатов, а также сами решения не вызывают серьезных возражений. В основном они были осуществлены в соответствии с действующим законодательством и вряд ли могли быть иными.

Таким образом, к сбору подписей избирателей были допущены 15 человек, а представили собранные подписи в ЦИК России (до 31 января) 6 кандидатов. В процессе сбора подписей из выборной кампании выбыли 9 кандидатов: Эльвира Агурбаш («Альянс зеленых»), Антон Баков («Монархическая партия»), Ирина Волынец («Народная партия России»), Екатерина Гордон («Партии “Добрых дел”»), Михаил Козлов («Партия Социальной Защиты»), Наталья Лисицына («РОТ Фронт»), Владимир Михайлов (самовыдвиженец), Станислав Полищук («Партия социальных реформ») и Роман Худяков («ЧЕСТНО»).

Сбор подписей избирателей в поддержку выдвижения кандидата на выборах Президента России - это весьма ресурсоемкая и финансово затратная процедура. Для сбора 100 тыс. подписей избирателей с 5\%-ным запасом, при условии, 


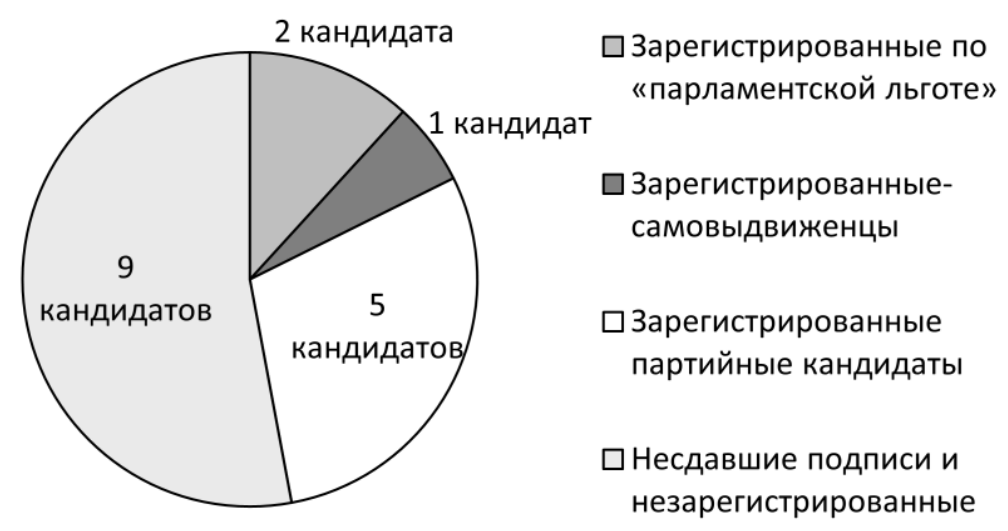

Рис. 3. Состав кандидатов на этапе регистрации

что в одном регионе можно собрать не более 2500 подписей, необходимо создать избирательные штабы в не менее чем в 42-43 регионах страны. Для качественного и оперативного сбора подписей желательно в каждом региональном штабе иметь порядка 30-40 платных сборщиков, организационную группу, а еще нужны юристы, нотариусы, помещение, транспорт, офисная техника, агитационные материалы, канцтовары, печать и доставка подписных листов. Поэтому представляется сомнительным, что ряд кандидатов (например, Антон Баков («Монархическая партия»), Ирина Волынец («Народная партия России»), Михаил Козлов («Партия Социальной Защиты»), Роман Худяков («ЧЕСТНО»), которые израсходовали менее 100 тыс. руб.), действительно пытались осуществить сбор подписей и намеревались принять реальное участие в выборах. Расходы более 2 млн руб., по-видимому, могут свидетельствовать о серьезности изначальных намерений кандидатов: самовыдвиженцы В. Путин и В. Михайлов, выдвиженцы от партий - С. Бабурин, Е. Гордон, К. Собчак, Г. Явлинский, Б. Титов. Выдвиженцы ряда партий малых партий «второго эшелона» попытались опереться на имеющиеся кадровые ресурсы партий. Из них, судя по всему, справиться с задачей удалось только М. Сурайкину («Комму- нисты России»). Самовыдвиженец Владимир Михайлов признался, что не рассчитал свои возможности и смог собрать только 100 тыс. подписей [12]. Однако действующий президент России Владимир Путин продемонстрировал, что это не является проблемой, если вы обладаете неограниченными государственными и финансовыми ресурсами (уже в самом начале кампании было объявлено, что он сформировал максимальный объем избирательного фонда в 400 млн руб.). По сообщениям штаба Владимира Путина, ими было собрано более 1,6 млн подписей, т.е. с 5-кратным запасом ${ }^{3}$, а сам сбор превратился в масштабную пиар-кампанию, активно освещавшуюся в СМИ.

Таким образом, представляется, что существующее требование собрать примерно за 30-35 дней 100 тыс. подписей для неадминистративных кандидатов, выдвинутых от непарламентских партий, является достаточно жестким, а 300 тыс. для кандидатов-самовыдвиженцев - явно завышенным.

В результате, по окончании этапа регистрации (этап регистрации кандидатов длился с 27 декабря 2017 г. по 10 февраля 2018 г.) количество кандидатов сократилось еще примерно наполовину. В выборах президента России продолжили принимать участие 8 кандидатов: Сергей Бабурин («Российский Общена-

\footnotetext{
${ }^{3}$ Штаб В.В. Путина подвёл итоги сбора подписей. 22.01.2018 г. [10]
} 
Итоги сбора подписей избирателей и расходы кандидатов на его обеспечение

\begin{tabular}{|c|c|c|c|c|}
\hline Кандидат & $\begin{array}{c}\text { Субъект } \\
\text { выдвижения }\end{array}$ & $\begin{array}{c}\text { Сдача собранных } \\
\text { подписей избирателей } \\
\text { или иных действия } \\
\text { кандидата }\end{array}$ & $\begin{array}{l}\text { Решение } \\
\text { ЦИК РФ }\end{array}$ & $\begin{array}{l}\text { Расходы на сбор } \\
\text { подписей (руб.) }\end{array}$ \\
\hline Титов Б.Ю. & Партия Роста & 30.01 .2018 г. & регистр. & 2879248 \\
\hline Худяков Р.И. & «ЧЕСТНО» & $\begin{array}{c}\text { 22.01.2018 снялся «в пользу } \\
\text { В.Путина» }\end{array}$ & - & 84540 \\
\hline Агурбаш Э.К. & «Альянс зеленых» & $\begin{array}{c}\text { Не представила подписи, } \\
\text { ранее партия заявила, что } \\
\text { прекращает участие в } \\
\text { выборах из-за давления на } \\
\text { ее членов }\end{array}$ & - & 47170,00 \\
\hline Явлинский Г.А. & «Яблоко» & 30.01 .2018 г. & регистр. & 20611344 \\
\hline Бабурин С.Н. & $\begin{array}{c}\text { «Российский } \\
\text { Общенародный союз» }\end{array}$ & 30.01 .2018 г. & регистр. & 3100000 \\
\hline Собчак К.А. & $\begin{array}{c}\text { «Гражданская } \\
\text { инициатива» }\end{array}$ & 31.01.2018 г. & регистр. & 4395055 \\
\hline Полищук С.П. & $\begin{array}{c}\text { Партия Социальных } \\
\text { Реформ }\end{array}$ & - & - & 11413440 \\
\hline Баков А.А. & Монархическая партия & $\begin{array}{c}\text { 24.01.2018 г. по } \\
\text { вымышленной причине }\end{array}$ & - & 47200 \\
\hline Гордон Е.В. & $\begin{array}{c}\text { «Партия “Добрых } \\
\text { дел”» }\end{array}$ & $\begin{array}{c}26.01 .2018 \text { г. снялась из-за } \\
\text { недовольства ходом } \\
\text { выборов («фарс») }\end{array}$ & - & 2071450 \\
\hline Козлов М.В. & $\begin{array}{c}\text { Партия Социальной } \\
\text { Защиты }\end{array}$ & $\begin{array}{c}\text { 31.01.2018 г. отказ сдать } \\
\text { подписи }\end{array}$ & - & 0 \\
\hline Сурайкин М.А. & $\begin{array}{c}\text { «Коммунистическая } \\
\text { партия "Коммунисты } \\
\text { России"» }\end{array}$ & 31.01 .2018 г. & регистр. & 415846,29 \\
\hline Михайлов В.В. & самовыдвижение & $\begin{array}{c}31.01 .2018 \text { г. отказ сдать } \\
\text { подписи, не смог собрать } \\
\text { нужное количество }\end{array}$ & - & 2636337,65 \\
\hline Путин В.В. & самовыдвижение & 29.01 .2018 г. & регистр. & 4373628,11 \\
\hline Лисицына Н.С. & $\begin{array}{l}\text { «РОТ Фронт» } \\
\text { (повторно) }\end{array}$ & $\begin{array}{c}31.01 .2018 \text { г. предъявила } 90 \\
\text { тыс. подписей, остальные } \\
10 \text { тыс., якобы, не успела } \\
\text { доставить Почта России }\end{array}$ & - & 120000 \\
\hline Волынец И.В. & $\begin{array}{c}\text { Народная партия } \\
\text { России }\end{array}$ & $\begin{array}{l}\text { 31.01. } 2018 \text { г. Снялась } \\
\text { «в пользу В. Путина» }\end{array}$ & - & $\begin{array}{l}\text { Нет сведений об } \\
\text { открытии } \\
\text { избирательного } \\
\text { счета }\end{array}$ \\
\hline
\end{tabular}

родный Союз»), Павел Грудинин (КПРФ), Владимир Жириновский (ЛДПР), Владимир Путин (самовыдвижение), Ксения Собчак («Гражданская инициатива»), Максим Сурайкин («Коммунисты России»), Борис Титов («Партия Роста»), Григорий Явлинский («Яблоко»).
В целом, среди зарегистрированных кандидатов остались наиболее ресурсные участники и наиболее опытные из выдвинувшихся политиков, за исключением Алексея Навального. Формально они представляли достаточно широкий партийно-идеологический спектр российской политики: от «просоветских левых»

\footnotetext{
${ }^{4}$ Согласно данным финансовых отчетов кандидатов, размещенных на сайте ЦИК РФ.
} 


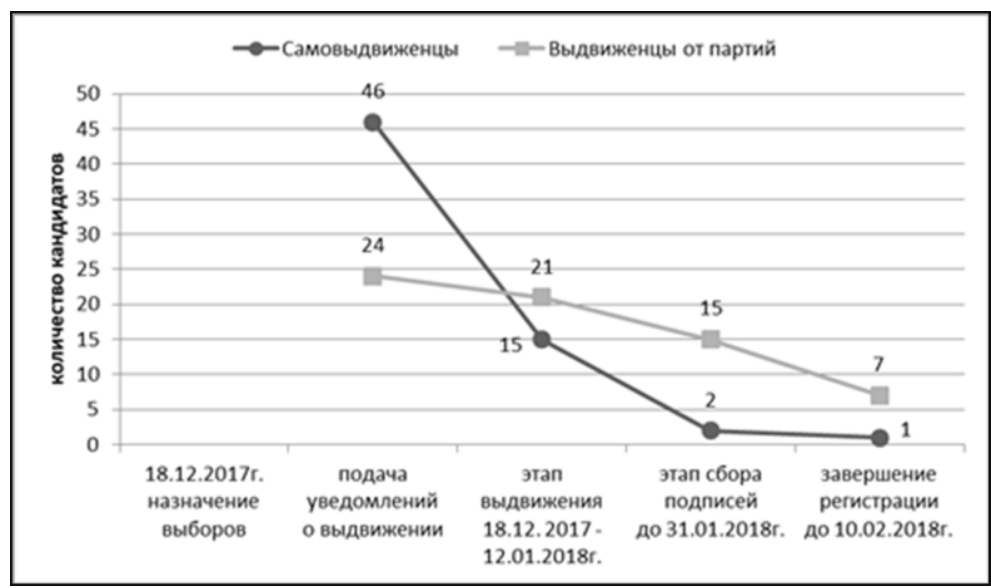

Рис. 4. Динамика количества кандидатов на выборах

Президента РФ 2018 г.

(М. Сурайкин), до «традиционалистов-государственников» и «национально-патриотических» сил (С. Бабурин, В. Жириновский, П. Грудинин); были представлены как представители умеренно-правых взглядов (Б. Титов), так и либеральных оппозиционных сил (К. Собчак, Г. Явлинский). Однако после этапа регистрации кампания приобрела ярко выраженный неконкурентный характер в силу безусловного преимущества действующего президента Владимира Путина над всеми остальными кандидатами.
При этом изменилась тактика отстранения конкурентов: если раньше не последнюю роль в этом играли избирательные комиссии или административные органы, которые принимали спорные решения, то теперь основания для принятия политически значимых решений были переведены в формальные правила законодательства, формальная ответственность за принятие которых была возложена на парламентариев, т.е. на сам «политический класс».

\section{Библиографический список}

1. Выдвижение кандидатов на выборах Президента Российской Федерации, назначенных на 18 марта 2018 года. Аналитический доклад. Доклад подготовили эксперты КГИ к.ю.н. А.Е. Любарев, к.п.н. A.В. Кынев, к.ю.н. А.Н. Максимов [Электронный ресурс]. URL: https://komitetgi.ru/analytics/3602/ (дата обращения: 03.08.2018).

2. Дело «Кировлеса» // Материал из Википедии - свободной энциклопедии. [Электронный ресурс]. URL: https://ru.wikipedia.org/wiki/Дело_«Кировлеса» (дата обращения: 03.08.2018).

3. Кампания Навального 2018. Как это было. [Электронный ресурс]. URL: https://2018.navalny.com/ (дата обращения: 03.08.2018).

4. Квасников B. Сколько денег Навальный собрал на выдвижение в президенты. The Village. 25.04.2018 [Электронный ресурс]. URL: https://www.the-village.ru/village/city/news-city/310499navalny-money (дата обращения: 03.08.2018).

5. Корня A. С иностранным видом на жительство избираться нельзя пожизненно. Ведомости 10.01.2018. [Электронный ресурс]. URL: https://www.vedomosti.ru/politics/articles/2018/01/11/747412izbiratsya-nelzya-pozhiznenno (дата обращения: 03.08.2018).

6. Любарев A.E. С чем связано оттягивание начала президентской кампании. [Электронный ресурс]. URL: https://www.golosinfo.org/ru/articles/142394 (дата обращения: 03.08.2018).

7. Навальный объявил «забастовку избирателей». Meduza 25.01.2018. [Электронный pecypc]. URL: https://meduza.io/news/2017/12/25/navalnyy-ob-yavil-zabastovku-izbirateley (дата обращения: 03.08.2018).

8. Любарев А.Е. О ключевых изменениях законодательства о выборах Президента России 2018 года в сравнении с выборами 2012 года. Аналитический доклад. Москва, 15 декабря 2017 г. [Электронный pecypc]. URL: https://www.golosinfo.org/ru/articles/142384 (дата обращения: 03.08.2018).

9. Кынев А., Любарев А., Максимов А. Российские выборы-2017: преемственность и изменение практик между двумя федеральными кампаниями. - М.: Фонд «Либеральная Миссия», 2018. - 514 с.

10. Сайт В.В. Путина. [Электронный ресурс]. URL: http://putin2018.ru/ (дата обращения: 03.08.2018). 
11. Сайт Центральной избирательной комиссии Российской Федерации [Электронный ресурс]. URL:http://www.cikrf.ru/ (дата обращения: 03.08.2018).

12. Самовыдвиженец Михайлов заявил, что не понесет в ЦИК подписи. РИА Новости. 31.01.2018. [Электронный pecypc]. URL: https://ria.ru/election2018_news/20180131/1513674829.html (дата обращения: 03.08.2018).

13. Федеральный закон от 21.02.2014 г. № 19-Ф3 «О внесении изменений в отдельные законодательные акты Российской Федерации» // СПС КонсультантПлюс (дата обращения: 03.08.2018).

14. Федеральный закон от 07.05.2013 г. № 102-Ф3 «О внесении изменений в отдельные законодательные акты Российской Федерации в связи с принятием Федерального закона «О запрете отдельным категориям лиц открывать и иметь счета (вклады), хранить наличные денежные средства и ценности в иностранных банках, расположенных за пределами территории Российской Федерации, владеть и (или) пользоваться иностранными финансовыми инструментами» // СПС КонсультантПлюс (дата обращения: 03.08.2018).

15. Федеральный закон от 12.06.2002 г. № 67-Ф3 «Об основных гарантиях избирательных прав и права на участие в референдуме граждан Российской Федерации» // СПС (дата обращения: 03.08.2018).

\title{
CANDIDATE REGISTRATION AS THE KEY STAGE IN HOLDING NON-COMPETITIVE ELECTIONS (BASED ON THE EXAMPLE OF THE ELECTORAL CAMPAIGN FOR THE RUSSIAN PRESIDENTIAL ELECTIONS ON 18 MARCH 2018)
}

\author{
V.S. Kovin \\ Perm Federal Research Centre UB RAS
}

The article considers the initial stages of the 2018 presidential election campaign in Russian Federation - the nomination and registration of candidates. The list of the participants is analyzed along with the reasons for their registration or non-registration. The article concludes that there are targeted policies of non-competitive campaigns in the elections of the executive government (based on the example of the presidential elections). These policies act as the main tendency that governs the electoral processes in modern Russia. The article also considers the main mechanisms used to achieve this aim. This research draws a conclusion that the emphasis in organizing the elections is put on establishing such formal rules and procedures that only system and resource politicians are able to comply with.

Keywords: presidential elections, competition, registration of candidates, election campaign.

\section{Сведения об авторе}

Ковин Виталий Сергеевич, кандидат исторических наук, старший научный сотрудник отдела по исследованию политических институтов и процессов, Пермский федеральный исследовательский центр УрО РАН (ПФИЦ УрО РАН), 614900, г. Пермь, ул. Ленина, 13А; e-mail: kovinvit@gmail.com 